\title{
Jürgen Habermas and Bush's Neoconservatives: Too Close for Comfort?
}

\author{
VIVIENNE MATTHIES-BOON \\ Department of International Relations and International Organisation, \\ University of Groningen, The Netherlands
}

\begin{abstract}
In his recent political writings, Habermas has opposed his cosmopolitan project to that of the Bushite neoconservatives. However, this article argues that in some respects Habermas's works come closer to the neoconservative agenda than he realises and that this poses a potential danger of its being appropriated by precisely the camp he opposes. These problems particularly come to the fore in his analysis of Islamic fundamentalism, democracy and the Middle East, but also in his recommendations concerning UN-based internationalism and his appeals to Woodrow Wilson. By tracking these problematic areas in Habermas's work, this article argues that Habermas needs to engage in a more carefully articulated, concrete and empirical analysis if he is to avoid these problems.
\end{abstract}

\section{Introduction $^{1}$}

In his recent political writings, Habermas has fervently opposed the neoliberal and neoconservative policies of the Bush administration. In opposition to this unilateral hegemon, which hides its power interests behind the ethical façade of spreading democracy and human rights abroad, Habermas argues, that we should instead embrace a cosmopolitan political order. Such a cosmopolitan order would be characterized by a multi-levelled system of governance and a further institutionalization of international law, as well as by the promotion of procedural opinion- and will-formation (Habermas, 2001, 2003, 2006a, 2006b). In advancing such a model, Habermas hopes to follow in the footsteps of Immanuel Kant, with a view to implementing a truly cosmopolitan world order devoid of illegal war (Habermas, 1997).

On first sight, this project seems admirable. After all, the invasion of Iraq by the "Coalition of the Willing," the institutionalization of torture and human rights abuses, the bending of international and national law, as well as the ideological rhetoric of the Western "us" versus the terrorist "them" is surely only to be deplored. Yet, as I shall argue, the relation between Habermas's work and the neoconservative outlook is more complex than his political utterances suggest. The

Correspondence Address: Vivienne Matthies-Boon, Department of International Relations and International Organisation, University of Groningen, Oude Kijk in 't Jatstraat 26, 9712 EK Groningen, The Netherlands. Tel.: +31 (0) 50363 7254; Email: e.a.v.matthies-boon@rug.nl 
problem is that on closer inspection there appears to be a hitherto unremarked affinity between Habermas's proposals and those of the neoconservatives. This raises the question of whether Habermas's work might not run the risk of being appropriated by the those he opposes - namely, by Bushite neoconservatives such as Paul Wolfowitz, Dick Cheney, William Kristol, David Frum and Daniel Pipes (among others) - in order to support their own ideological agenda rather than Habermas's cosmopolitan project ${ }^{2}$. Indeed, John Yoo and Robert Delahunty (2010) have already done just this. For the irony is that, despite the fact that Habermas clearly opposes his approach to that of the neoconservatives, he in the end affirms at least some of the core ideological values and perceptions of the Bush administration. Three central instances are these. First, like the neoconservatives, Habermas (2003) espouses a belief in the universal value of democracy; like them (and of course like many others) he believes that a spread of democracy to the Middle East will lead to a peaceful and prosperous future, as well as the demise of Islamic fundamentalism. Second, just like the neoconservatives and their allies, whether explicit or implicit, Habermas fails to look into the important influence of colonialism and postcolonialism in the region and believes that the mere imposition of proper formal democratic processes would lead to a resolution of political violence. Like the neoconservatives, he fails to analyse the historical, political, social, cultural and economic role of the West and other occupying forces have placed in the Middle East. Rather, he sees the region and the problems of fundamentalism that emanate from it through the lens of his largely Western-based theory of modernity, with all the problems that brings. Third, in his opposition to the neoconservatives, Habermas (2008) frequently appeals to the internationalist stance of Woodrow Wilson and posits this as an alternative approach to the Bush administration (p. 94, pp. 155-158). Yet, what is interesting here is that the Bush administration itself frequently referred to the Wilsonian legacy in order to legitimate its own imperialist projects (p. 94, pp. 155-158). Moreover, in his appeals to Wilsonianism, Habermas overlooks the extent to which Wilson himself was engaged in the imperialist spread of democracy to Latin America and other parts of the world (Encarnación, 2005). While this does not necessarily imply that Habermas's own project has imperialist tendencies, it does indicate that Habermas has failed sufficiently to reflect on the affinity between some aspects of his own work and the core imperialist ideological beliefs of neoconservatism. My worry is hence that Habermas might all too easily be coming close to what he criticizesand thus might run the danger of being systematically appropriated by neoconservative ideologues.

Of course, Habermas differs from the neoconservatives in his analysis of the free market and its putative benefits, arguing that, against the neoconservatives, the market needs to be brought under control by democratic institutions on a global level. The difficulty here, however, is that, practically at least, Habermas's accounts rely on a rather naïve analysis of the concrete workings of international institutions such as the UN. He argues that these kinds of institution will be able to open up the way for a truly cosmopolitan future, but fails to see the extent to which these institutions have themselves become informed, even dominated, by neoliberal values. This oversight is, I believe, due not only to the abstract nature of 
Habermas's account but also his own implicit endorsement-and however much that goes against his explicit position — of the apparent benefits of the free market.

The intention of this article is thus neither to repudiate cosmopolitan political philosophy nor to strengthen the visions of the neoconservative camp. Rather, my aim is much more modest than that: I seek merely to put out a warning sign, to point out that Habermas - and Habermasians - need to reflect more carefully and closely on the possible affinity between his work and the positions and commitments of the neoconservatives. Not least because, as I have said, neoconservatives have already incorporated insights from the progressive left in order to advance their own program, such a task is as politically urgent as it is intellectually salutary. In order to relay this warning sign, I shall first outline Habermas's proposals for a cosmopolitan world order, in the course of which he opposes his own work to that of the neoconservatives. I shall then proceed to his political commentary on Islamic fundamentalism where some affinities between his approach and that of the neoconservatives come to light particularly sharply. Following this, I shall analyze the extent to which his proposed cosmopolitan resolution to the problems of the Middle East offers a viable alternative to the imperialist project of the neoconservatives, questioning especially the extent to which international institutions such as the UN offer a practical alternative to the neoliberal ideology of the neoconservatives. Finally, I shall go on to point out the oddity of Habermas's appeals to the internationalist Wilsonian legacy, a legacy explicitly exploited by the Bush administration in the development of its "Freedom Agenda."

\section{Habermas's Multilateral Cosmopolitan Governance vs. Neoconservative Unilateral Imperialism}

In his recent political writings ${ }^{3}$ Habermas (2009) argues against the neoliberal and neoconservative actions and outlook of the Bush administration, and while he endorses the Obama administration (p. 185) the latter hardly signals anything very different (Khan, 2011, p. 21). The trigger for Habermas was the invasion of Iraq, where the Coalition of the Willing commenced the "Shock and Awe" strategy without a resolution from the Security Council. What angered him was not only the illegitimacy of the war itself, but also that the United States plainly ignored, sidelined and even sought to modify international law as it pressed its own interests upon the international community (Habermas, 2006a, p. 182). This, he insists, is a dangerous precedent: one that could potentially lead to a crumbling of the cosmopolitan order. For Habermas (2006a) believes that, with the formation of the $\mathrm{UN}$, the establishment of International Courts, and the enforcement of human rights, the international community has slowly but surely moved beyond classical international law-which merely governed inter-state relations-towards a cosmopolitan legal order. Hence, by bypassing the UN, the Bush administration went directly against the evolving cosmopolitan world order that Habermas advocates.

Since 2003, Habermas has thus been more active in his condemnation of the neoconservative outlook and also stepped up his own campaign for a normative cosmopolitan alternative. In this campaign, he posits an alternative cosmopolitan 
project that would be free of any despotic or imperialist traits, owing to the fact that it would bring democracy into being across the globe, ensuring that "no one could unilaterally determine the boundaries of what is tolerated" (Habermas, 2003, p. 40). There is, hence, no one agent who can impose their will on others. Rather, the world is offered a rational model where opinions and will-formations are discursively created and multilateral, rather than unilateral, actions are undertaken. Central to this cosmopolitan framework are international organizations such as the United Nations. By this model, it would function as a global police force, regulating and inspecting the behaviour of nation states so as to ensure that they adhere to human rights and to international law (Habermas, 2004). In order to ensure that such a global order led by the UN would not begin to take on the characteristics of a despotic world state, Habermas proposes a multileveled model of governance. In such a model of governance, supranational institutions spanning the entire globe would be supported, informed and influenced by the discursive features of a broad range of actors: from social movements to nation states to regional blocks. Within this order, transnational regional institutions such as the EU would play an important role as they would be able to bring the interests of an entire region to the attention of the $\mathrm{UN}$ and solve many of their problems transnationally.

Here, Habermas clearly builds further on his earlier proposals for a stronger integrated European Union based on the idea of a constitutional patriotism, ${ }^{4}$ which he posited as another necessary tool to counter American neoconservativism (Habermas, 2001). A stronger, integrated Europe was necessary, he argued, both to counter American imperialism on a world stage, as well as to deal with problems caused by global economic forces that could no longer be contained at the level of individual nation states. ${ }^{5}$ Europe would be the prime actor fighting the corner of cosmopolitanism against the unilateralist neoconservative policies of the Bush administration and its followers as it pushes for international multilateralism and the further institutionalization of democracy.

Moreover, referring to historical instances such as the Second World War and postcolonialism, Habermas insists that Europeans are particularly well suited to play this civilizing role. For, in contrast to the United States of America, Europe has a stricter division between church and state, a greater sensitivity towards human rights as a result of decolonization and, most of all, Europe has been on a cosmopolitan learning curve as a result of the painful experiences of the Second World War (Habermas, 2005, p. 11; see also Boon, 2007, p. 297; 2009, pp. 31-34). In these works, he argued passionately against any actors, such as the heads of state in Central and Eastern Europe, as well as the United Kingdom, who favoured a weaker rather than a stronger European Union (Boon, 2007, p. 293; Habermas, 2005 , p. 5). For him, the threats posed by American neoconservativism are so serious that there is no other choice: either Europe takes on this civilizing role or cosmopolitanism will fail and the USA's imperialist unilateralism will triumph (Habermas, 2006a, p. 52).

It is imperative to note here that, for Habermas, this cosmopolitan struggle against the imperialist tendencies of the United States is not a fight against the idea of the West as such: rather, he positions his work firmly within the Western political tradition (Habermas, 2006a, p. 50). Moreover, he fears that any general arguments 
against the idea of the West could end up throwing out the baby with the bathwater, that is to say, they could lead to an outright rejection of the communicative rationality which for him clearly developed on the Western side of the Berlin Wall (Habermas, 2005, p. 9). Instead, by positioning communicative rationality (that of the social realm, the lifeworld) in direct opposition to instrumental rationality (that of the economic system) he argues that the tragedy of modernity is a one-sided development of reason (Habermas, 1984, 1985, 1987b). This one-sided development of reason means that instrumental rationality (which is focused merely on achieving strategic ends) has encroached on the lifeworld (characterized by reaching understanding) (Habermas, 1987a, 1987b). Thus what needs to happen is an opening up of communicative channels so that the system can be brought under the control of the lifeworld once again.

\section{Habermas on Islamic Fundamentalism: The Desired End of Western Democracy}

It is also on the basis of this perspective of his Western-based theory of a one-sided rationality that Habermas interprets the phenomenon of Islamic fundamentalism. ${ }^{6}$ In his interview with Borradori, Habermas perceives Islamic global terrorism as a thoroughly modern phenomenon bound up with modernizing processes and the alienation caused by economic misery. He explains that the same globalizing and modernizing processes that swept through Europe are now sweeping through the Middle East. ${ }^{7}$ Yet, in Europe these modernizing processes were at least compensated for by significant benefits, whilst the Middle East has only seen a widening gap between the economic winners and losers (Habermas, 2003, p. 32). The upshot is that in the Middle East "a process of productive destruction does not hold the same promise of compensation for the pain of the disintegration of customary ways of life" (p. 32).

Hence, rather than perceiving Islamic fundamentalism in light of Huntington's thesis of the clash of civilizations, Habermas (2003) points towards its economic causes. Given these economic origins, he does not deem it surprising that the terrorists chose to strike at the heart of the capital enterprise of the USA, the country regarded in the Arab world as the driving force of capitalist modernization. He remarks that "the West in its entirety serves as a scapegoat for the Arab world's own, very real experience of loss suffered by populations torn out of their cultural traditions during processes of accelerated modernization." Nevertheless, "with its unapproachable lead in development and with its overwhelming technological and economic, political and military superiority, the USA appears as an insult to their self-confidence whilst simultaneously providing a secretly admired model" (p. 32).

It is this level of frustration caused by economic deprivation, he argues, that has led religious fundamentalists to have recourse to pre-modern beliefs and traditional notions of identity. For the alienation caused by the uprooting of a way of life makes people yearn for a return to a shared, pre-modern, meaning-endowing identity (Rosenfeld, 2007, p. 159). This yearning is unrealistic, however, in that in modern complex societies an exclusive claim to truth by one faith can no longer be maintained. So, if Middle Eastern societies want to renounce such dogmatic attitudes, they would need to embark upon a path of self-reflexivity akin to the one 
undertaken in Europe. For "in Europe, the confessional schism and the secularization of society have compelled religious belief to reflect on its nonexclusive place within a universal discourse shared with other religions and limited by scientifically generated secular knowledge" (Habermas, 2003, p. 31). As long as "fundamentalists - and states like Iran - strive for the reestablishment of an Islamic form of theocracy, they repress any cognitive dissonances and thus remain tied within a fundamentalist framework" (pp. 31-32). In order to embark on this journey of enlightenment and be able to grapple with cognitive dissonances, what needs to be improved is - rather unsurprisingly-communication.

For, while it is economic problems that underlie Islamic fundamentalism, the issue can be solved by rectifying patterns of distorted communication. After all, these conflicts primarily "arise from distorted communication, from misunderstanding and incomprehension, from insincerity and deception." (Habermas, 2003:35) It is here that the spiral of distorted communication begins, which then leads to mutual mistrust, eventually resulting in a complete breakdown of communication. This spiral of distorted communication is further strengthened by the fact that both the Islamists and the Bush administration are geared towards strategic action rather than communicative action, in that they both seek to achieve their particular ends rather than reach understanding. Yet Habermas (2003) does not lose his optimism for "if violence. . . begins with a distortion in communication, after it has erupted it is possible to know what has gone wrong and what needs to be repaired" (p. 35); namely, communication. However, in terms of repairing communication, his proposals remain rather abstract and vague. First, he puts forward a general argument for a stronger legal international order and a particular reinforcement of the UN. At the moment, the UN is reduced to the proverbial paper tiger, but with some further encouragement the cosmopolitan seeds within the UN can grow and can begin to flourish on a world stage (p. 39). Second, he argues that a model of democratic constitutionalism can be seen as a solution to the problems pestering the Middle East: for he insists that only such a deliberative political order would enhance reflexivity so as to be capable of incorporating civil disobedience, even beyond its own boundaries of tolerance ( $p$. 41). A constitutional democracy is reliant on an active civil society, and will be able to incorporate Islamic resistance. As he explains, "the democratic project of the realization of equal rights actually feeds off the resistance of minorities, which, although appearing as enemies of democracy to the majority today, could actually turn out to be their authentic friends tomorrow." Not only that, but a constitutional order would also ensure that a universalistic liberal legal order is established, characterized by an "egalitarian individualism of a morality that demands mutual recognition, in the sense of equal respect and reciprocal consideration for everybody" (p. 42). As Michel Rosenfeld (2007) nicely points out, the gist of Habermas's story thus seems to be that

From the standpoint of Muslim societies ... communicative action would lead to the abandonment of authoritarianism, and the use of Islam to inflame masses. Muslim politics could willingly embrace the material gains of a globalization fine-tuned to promote equal opportunities and social justice. Moreover, Muslim societies would adjust their own lifeworld and legal and political institutions in order to reconcile Islam, modernism and fair and responsible globalisation. The resulting Islam would 
not be fundamentalist but accepting of pluralism, like other great religions that have adjusted to the conditions of modern multiculturalism. (p. 168)

However, such a conception is highly problematic. The first notable difficulty is that Habermas nowhere directly engages with Islamicist political thought or even with Middle Eastern politics. As a result of this, Habermas, like the Bushite neoconservatives, directly equates the problem of Islamic fundamentalism with the turbulence of Middle Eastern politics and society. And as Middle East expert Olivier Roy (2008) explains, this is a mistake commonly made by Western commentators, and serves to allow them to project familiar problems that exist in Europe (caused by migration) onto the quite different area of the Middle East. Yet that this projection is ambiguous comes to the fore when one realizes that

Al Qaeda's recruitment map [does not necessarily] mirror conflicts in the Middle East, since there is a predominance of young second generation European Muslims and converts, but there are no Palestinians or Afghans and very few recruits from the Middle East. The Islamists, like the Arab Muslim Brotherhood, are not involved in international terrorism. Nor do neofundamentalists [within the Middle East] recruit in traditional milieus, but instead among migrants, refugees, the second generation, the new social classes, or among tribes undergoing change. (p. 52)

Hence the move from the problem of Islamic fundamentalism directly to Middle Eastern politics is rather too quick in Habermas's account, just as it is too quick in the neoconservative's worldview, where " $9 / 11$ " was the directly invoked reason to invade Iraq in 2003. Of course, I am not claiming here that Habermas's model would lead to, or even directly encourage, such direct invasions, but rather I am making the more modest claim that both strands of thought are engaged in the same mistake of projection and that a more careful, sensitive and differentiated empirical analysis is needed.

Worse even than this, however, is the fact that Habermas's perception of Islamic fundamentalism and the Middle East is not only inaccurate, but also extremely offensive. It is offensive in that he completely ignores the complex colonial history of the Middle East and merely interprets these issues in light of his western theory of modernity (Habermas, 1979a, 1987a). This theory of modernity is anyway problematic, in that it is based on his account of social evolution which (despite his own assertions) leads him to interpret historical events in an evolutionary line that culminates in a cosmopolitan post-conventional order. This evolutionary line is modelled explicitly on Western developments (Boon, 2009, chapter 2). The upshot of this is that when he looks at Middle Eastern affairs, it becomes a case of these "Middle Easterners" needing to become more like "us." They are simply lagging behind on the evolutionary scale, and need to become more reflexive, as well as to implement a constitutional democracy. Only when they discover the fruits of liberal democracy will they find peace and security. The complexity of Islamic fundamentalism as well as Middle Eastern politics is reduced and their alterity changed into familiar Western concepts which, of course, ensures that the West gets off extremely lightly. For example, while at one point he remarks that disappointment with an autocratic regime might boost Islamic fundamentalism, he nowhere reflects on the active role of the West in keeping these regimes in power. At no point does Habermas refer to the legacy of colonialism or to the unfair 
policies inflicted upon the Middle East by the Western powers both in the present and in the past. He does not even mention Western meddling, interference and cheating in Middle Eastern affairs-let alone the three biggest traumas inflicted upon the Middle East in recent history, namely the Sykes Picot agreement in 1916, the establishment of the State of Israel in 1948 and the overthrow of the Sunni political primacy in the Middle East as a result of the 2003 Iraq invasion (e.g. Roy, 2008, pp. 76-79). But given this colonial history, it is simply outrageous to argue that the very same processes of rationalization that occurred in Europe are now taking place in the Middle East. For a start, we might point out that Europe has not been recently colonized. ${ }^{8}$ Hence, rather than seeing the Middle East's alterity, he insists that it is simply the economy that is to blame, rather than Western political order itself having any role. But this is simply untenable.

His blindness to the colonial past also stops him from questioning the values of a liberal constitutional democratic order, values which are not automatically shared by many actors in the Middle East. In fact, much of the Islamist ideology that Habermas criticizes developed in direct response to Western developments and Western concepts of individualism, liberty and freedom. He completely overlooks this relation between Islamicism and Western ideologies, such as nationalism, liberalism and socialism, none of which were seen by the Islamists as viable and authentic alternatives to the autocratic regimes in the Middle East. The reason why these strands of thought were deemed unsuitable by the Islamists was precisely because they were tainted by Western (conceptions of) reason and thus lacked the requisite authenticity when transferred to a different context (Roy, 1998, passim). This kind of objection can be properly acknowledged only if one takes into account the impact of colonialism and post-colonialism which Habermas simply ignores. To offer liberal democracy as a response to problems arising at least in part out of that democracy and from responses to it is neither realistic nor respectful of those formerly colonized.

In this matter in particular, the issue is that Habermas comes closer to the neoconservatives than he realizes. For they too looked for the root causes of Islamic terrorism and they too ruled out any direct Western responsibility for radical Islamic violence (Roy, 2008, p. 29). Rather,

in their view, the source of this violence is the Arab societies' institutional structures which are hindering human, political and economic development. . . . For the neoconservative lobby, the structural explanation of terrorism argues that it is spawned by poor "governance" of the Muslim countries in general, and of Arab ones in particular. (p. 29)

It is the lack of such governmental structures that keeps "them" from becoming like "us." Hence, like, Habermas, they "are diametrically opposed to Huntington's 'clash of civilisations' theory" (Roy, 2008, p. 30) and, again like Habermas, they seek to resolve the problem of Islamic fundamentalism through the development and export of formal democratic political institutions. Hence, like Habermas, they are in favour of the development of active civil societies, which for them too are positioned in-between the state and the individual and can hold a potentially authoritarian state to account (Roy, 2008, p. 34). They too believe that encouraging a vibrant civil society will resolve and incorporate the difficulties of Islamic terror. 
Hence, both Habermas and the neoconservatives take the ends of democracy, individualism and an active civil society for granted and see the creation and strengthening of democratic political institutions as a viable-indeed as the onlyresponse to the problems of the Middle East. But neither Habermas nor the neoconservatives engage with concrete processes on the ground. Their theoretical and/or ideological preferences leads them both to posit as desirable the goal of formal democratic processes based on the Western democratic model, without any empirical analysis, without allowing the people on the ground any voice.

\section{International Institutionalism vs. Neoliberalism?}

However, where the neoconservatives and Habermas differ is in their respective analyses of the benefits of the free market. ${ }^{9}$ The former's neoliberalism demands that the primary role of the state or international institutions is not to counter the negative effects of the market, but rather to encourage its growth. Or rather, as Roy puts it, "for the neoconservatives democracy implies the full acceptance of the market economy, and therefore of privatization" (Roy, 2008, p. 31). Hence, in contrast to Habermas, the neoconservatives have a very limited conception of politics, namely as one the primary aim of which is not to interfere with market forces (e.g. Hassan, 2009, p. 25). In contrast, for Habermas the market should not be entirely "free," on account of its negative effects on processes of rationalization and its unequal distribution of wealth and resources. Rather, he insists, the market needs to be brought under the control of international regulation and deliberation through multilateral organizations such as the UN.

Yet there is a practical difficulty here: namely, that the UN, given in Habermas's work the task of bringing the market under control, has in fact become one of the prime agents for the promotion of market values across the world. So how exactly can this institution further his cosmopolitan approach? Without a more detailed, empirically informed and concrete analysis, Habermas's appeals to the UN as the harbinger of cosmopolitanism are at best empty and at worst stand to lend legitimacy to the very neoliberal order that he opposes. For since the former Secretary-General Kofi Annan reformed its institutions and redesigned the rationale and conduct of many of its programs at the end of the 1990s, the UN has embraced the free market and sought to spread "democracy" and "good governance" across the world. The perceived benefits of the market were notably lauded in a speech given by Kofi Annan to the World Economic Forum in Davos in 1997, where he stated that the UN should from now on promote "economic and political liberalization and the development of dynamic private sectors as the best strategy for effective peace-keeping across the world" (Cammack, 2006, p. 6). He even went so far as to argue that

First, there is a universal understanding that market forces are essential for sustainable development. Second, the role of the state is changing in most of the developing world, from one that seeks to dominate economic life to one which creates the conditions through which sustainable development is possible. Third, there is growing and compelling evidence that the poor can solve their own problems if they only are given fair access to business and development services. (Annan, 1997) 
This announcement set the tone for the transformation of the UN's developmental policies, which held that a growth in global trade was advantageous and mostly that the poor should by no means be excluded from the benefits unleashed by the global market. Not only that, but private market forces were perceived as the primary and lasting solution to instability and insecurity. Hence, Annan even insisted that

in today's world the private sector is the dominant engine of growth; the principal creator of value and wealth; the source of the largest financial, technological, and managerial resources. If the private sector does not deliver economic [sic] and economic opportunity-equitably and sustainably_around the world, then peace will remain fragile and social justice a distant dream. (Annan, 1997)

This view, naïve in its analysis of market forces as it may be, has since continued to set the tone for the UN's institutional structure and content of its development programs. Basically, the UN now merely ensures that the right infrastructures for the flow of capitalism are put in place, after which it leaves it up to the people in a particular country or area to grab their opportunity and buy into market logic in order to help themselves. In other words, rather than providing structural development money for the state or state-sponsored institutions, the UN has now cultivated a kind of do-it-yourself model of development entirely in line with the neoliberal agenda (Berger, 2001). The role of the state is thus reduced to that of facilitating capitalist market forces, and is actually held accountable by the international institution if insufficient progress has been made on this front. This progress has been further developed and monitored by a competitive model of peer review since the Brussels Declaration and Program of Action in 2001. Here, "model" apprentices ${ }^{10}$ are accorded the honour of reviewing their less performing peers, i.e. ones that had not made as much progress in economic liberalization in order to help spread "good practice" (Cammack, 2006, p. 16).

This belief in competition and the logic of free market has been further entrenched in the United Nations through its institutional reforms, for example the closer collaboration between the Economic and Social Council, the UN Commission on Trade and Development the Bretton Woods organisations (the IMF and World Bank) and the World Trade Organisation ${ }^{11}$ (Cammack, 2006, p. 11). It is clear that the Secretary-General believed in the poverty reduction programs led by the Bretton Woods institutions and carved out a special role for the UN in further facilitating these neoliberal programs. An active link in this closer cooperation and the further development of the neoliberal agenda within the UN was Mark Malloch Brown, a "completely self-confessed free-trader," who had previously served as the World Bank's "chief propagandist (Vice-President and Director of External Relations)" before becoming the United Nations Development Program Administrator (Cammack, 2006, p. 11; see also UN, 2011). He pushed forward an interventionist agenda where the UN institutions, in close collaboration with the IMF, would act to open up markets in developing countries. It is for instance this kind of vision that is at the heart of the Millennium Development Goals, adopted in September 2000, which sought to eradicate poverty, enhance rights and protect the environment through the standard panacea of so-called transparency and good governance.

Studies in Social Justice, Volume 5, Issue 2, 2011 
The point of this brief discussion of the United Nations reforms and its embracing of neoliberalism is to show how hard it is to regard the UN as one of the leading agents in a cosmopolitan model such as that proposed by Habermas. For in Habermas's account, the international institution would not only counter the neoconservative unilateralist point of view, but also correct market forces communicatively. In practice, however, it seems that the $\mathrm{UN}$ is doing precisely the opposite: it is opening up markets under the banners of democracy, good governance and human rights. So when the UN states that "good governance at the national and international level; the rule of law, respect for all internationally, human rights [...and] the promotion of democracy [...] are all essential in order to realize the vast and untapped human and economic potential in LDCs [Least Developed Countries] [emphasis mine]"(UN General Assembly, in Cammack, 2006, p. 14) what might be Habermas's response? After all, this kind of reasoning is precisely what he opposes, when he argues, against the Bush administration, that "the West presents itself in a form deprived of any normative kernel so long as its concern for human rights only concerns the attempt at opening up new free markets" (Habermas, 2003, p. 33). This in turn leads one to wonder how Habermas could possibly have just overlooked the neoliberal ideology underpinning these international institutions. Admittedly, his is a highly abstract and idealized account, and one which perhaps inevitably leads him to cherry-pick those instances that suit his own theoretical framework and to see actual developments through social evolutionary-tainted lenses. ${ }^{12}$ Nevertheless, the oversight is in the circumstances remarkable.

How might it be explained? Might the explanation lie simply in Habermas's own implicit belief in and endorsement of capitalist market forces? While he of course criticizes the one-sided rationality of market forces, his very distinction between the communicative realm and the realm of the system seems to posit the capitalist system as a necessary ingredient for modernization (Boon, 2010, p. 159). For the structural problems caused by the economic system lead to developments in the social realm as it seeks new solutions: in other words, the market is a necessary condition of evolutionary development. But even if that were too harsh a reading of Habermas, it would make no difference to the present problem. For Habermas agrees with Kofi Annan that "today, market capitalism has no major ideological rival." (Annan, 1997) when he claims that "since 1989-1990 it has become impossible to break out of the universe of capitalism; the only option is to civilise and tame the capitalist dynamic from within" (Habermas, 2009, p. 187) through communicative processes. But given his "realism" about capitalism, one might have expected Habermas at least to offer an explanation of how the facts of "actually existing capitalism" do not render his communicative idealism redundant just as they render redundant other ideals; and to show how his own approach is compatible with capitalist realities, in particular, how the UN can serve in the way he envisages to ensure that capitalism "promote(s) both prosperity and justice" as Annan hopes it might (Annan, 1997). But he does not. Nowhere in his work does Habermas offer even a minimal account of how capitalism might be open to "communicative adjustment." 


\section{Wilsonian Internationalism vs Neoconservativism?}

The final element of affinity between Habermas and Bush's neoconservative project is their common appeal to the internationalist legacy of Woodrow Wilson. When countering Bush's unilateralism, Habermas appeals to the American Wilsonian legacy in order to remind the neoconservatives of what he perceives as America's multilateral and cosmopolitan traditions (Habermas, 2006a, p. 156), hoping in so doing that the neoconservatives will see the light and embrace a more cosmopolitan future: for he firmly believes that Wilsonian internationalism will lead to a spread of liberal democracy and the international rule of law across the globe. Yet, as I will show, this appeal to Wilsonian internationalism in fact again indicates a somewhat uncomfortable closeness between Habermas and the neoconservatives.

After all, the neoconservatives could not themselves agree more with Habermas's appeal to Wilson. They remember Wilson very well. Wilson believed: (1) that the spread of democracy across the world would bring peace and prosperity (a thesis now known as democratic peace theory ${ }^{13}$ ); (2) that democracy was a universal value; (3) and that no one was incapable of self-government (including those people in Latin America deemed by many as unsuited for self-governance at the time); and (4) that, most importantly, the United States was the bearer of the moral project of spreading democracy across the world (Encarnación, 2005). On the basis of these beliefs, Wilson himself had actively and unilaterally intervened in Latin America, where he sought to install democracy with the aim of leading people to democratic enlightenment under America's specific patronage. Now, in the Bush administration such a Wilsonian streak became most pronounced after " $9 / 11$," when the ideologically loaded Freedom Agenda was explicitly developed by the White House to spread both democracy and the benefits of the free market to the Middle East, starting with Iraq (see Hassan, 2009, p. 194). Thus, Wilson's interventionist and internationalist philosophy was at the heart of Bush's intervention in Iraq (Dueck, 2003; Hassan, 2009). ${ }^{14}$ Crucial for this idealist agenda was the Wilson-inspired interventionist belief that democracy should be spread across the Middle East, that everyone (including Arab Islamic believers) was capable of engaging in democratic processes and that the USA had a special duty to fulfill in this respect (see Hassan, 2009). The White House thereby broke with American policy that had been fearful the spread of democracy would result in the election of an anti-American Islamist government (Encarnación, 2005, p. $47^{15}$ ) and instead insisted that only the imposition of a democratic order in Iraq would install peace and security in the region. As Bush stated at the time,

The world has a clear interest in the spread of democratic values, because stable and free nations do not breed the ideologies of murder. They encourage the peaceful pursuit of a better life. And there are hopeful signs of a desire for freedom in the Middle East. Arab intellectuals have called on Arab governments to address the "freedom gap" so their peoples can fully share in the progress of our times. Leaders in the region speak of a new Arab charter that champions internal reform, greater politics participation, economic openness, and free trade. And from Morocco to Bahrain and beyond, nations are taking genuine steps toward politics reform. A new regime in Iraq would serve as a dramatic and inspiring example of freedom for other nations in the region. (Bush, 2003)

Studies in Social Justice, Volume 5, Issue 2, 2011 
Bush clearly believed that, in terms of Middle Eastern politics, "democracies would not fight each other, they would all recognise Israel, whose security would be guaranteed by the democratization of the Arab countries. Terrorism would no longer be an option. The domino theory would operate for the benefit of the West" (Roy, 2008, p. 40). And so the neoconservatives carved out a special role for the United States of America, just as Wilson had believed that "as the definite example of democracy, the United States had a special obligation to extend its benefits and to instruct backward peoples in its uses" (Wilson cited in Encarnación, 2005, p. 49).

The difficulties that arise from the above is that Habermas's own appeals to the Wilsonian legacy are insufficiently informed by a critical analysis of what this Wilsonian legacy might entail. Had he undertaken a critical, historical and more empirical analysis of Wilson's thoughts and actions, he might have realized that Wilson was a dubious basis for an internationalist cosmopolitan project. Indeed, given this rather ambiguous legacy it is questionable as to what extent reference to Wilson would do anything but affirm a belief in spreading democracy abroad. Of course Habermas insists on a multilateral variant of the institutionalization of global democracy through international multi-levelled governance: but the point remains that Wilson undertook an active policy in exporting and imposing democracy abroad. By appealing to this legacy Habermas all too easily positions himself closer to this agenda.

My point is not that Habermas himself favours the forceful imposition of democracy from above by a third party, but rather that he has to be far more careful in his choice of historical ally if he is to avoid seeming to propose something all too easily compatible with, and even uncomfortably close to, the neoconservative agenda. For his close association with the Wilsonian legacy leaves him vulnerable to being appropriated by those he seeks to oppose. Habermas opens the way for the neoconservatives to employ his own citation of Wilson to advance their own agenda, particularly in respect of Habermas's arguments that a constitutional democracy would solve problems of Islamic fundamentalism. Of course, every theorist and every philosopher could be appropriated, twisted and used for ends they oppose. But this risk of appropriation needs surely to be anticipated, especially in an instance such as this, where the neoconservatives incorporate insights originating in the political left: principled interventionism, an insistence on human rights and freedom, the advancement of civil society and the promotion of democracy. Is Habermas really unaware that, as Roy has it, the neoconservatives "are closer to a left-wing progressivism that rejects cultural relativism of any kind rather than to a colonialism anxious above all to maintain the prevailing order" (Roy, 2008, p. 4)?

\section{Conclusion}

Habermas's commitment to cosmopolitanism stands in danger of being appropriated by a very different form of cosmopolitanism than his own: a neoconservative cosmopolitanism. For what else is the Project for the New American Century (1997) if not one sort of cosmopolitanism, however partial, self- 
interested and ruthless? To avoid such misappropriation, Habermas needs explicitly to differentiate his cosmopolitanism from theirs and to anticipate the contours of how such misappropriation might occur. Otherwise not only can his own arguments come inadvertently to be invoked to buttress a neoliberal agenda, just as have other arguments from the left over the last twenty or more years, but the very idea of a left-wing cosmopolitanism might all too easily be lost in consequence. Though the responsibility is an onerous one, it cannot be shirked.

\section{Notes}

1 This paper has significantly benefitted from conversations with Andrej Zwitter, Jaap de Wilde and my husband Tim Matthies. Thanks also to Bob Brecher for his patience.

2 Neoconservativism of course has a longer history of thought development as well as political action than the Bush administration and is by no means limited to the United States of America. However, since I am preoccupied here with a perceived problem in Habermas, I am restricting the term neoconservative to that of the Bushite ideologues, the primary target of Habermas's own recent political critiques. For more information on neoconservativism prior to Bush, please see Gerson, 1996.

3 Some commentators on Habermas would make a distinction between his political and theoretical works: however, as I have shown (see Boon, 2009) Habermas himself muddles these two distinct analytical categories in his work. For this reason I will not pose an analytical distinction between these two modes of writing and instead take them as a whole.

4 "Constitutional Patriotism" was originally a term developed by Dolf Sternberger for a particularly German situation (namely unification). Habermas adopted it to suit his European project, and argued that this would open the possibility for a model of European integration not based on thicker cultural notions of identity, but on thin legal principles (Habermas, 1996). The irony is that Habermas nevertheless searches for thicker notions of European identity to counter American imperialism and as a means of endorsing his European project of constitutional patriotism (Boon, 2009, chapter 1; Müller, 2000, p. 94).

5 As I shall note in more detail in section 3, Habermas's analysis of the benefits of the free market is hence somewhat different from that of the neoconservatives, who regard the advancement of the market as one of their primary aims on account of its being, for them, a primary good.

6 For an earlier critical reading of Habermas's comments on Islamic fundamentalism, see Boon, 2010.

7 Habermas' comments on Islamic fundamentalism occur prior to the Arab Spring in 2011-for a critical analysis of the relation between Habermas' comments on Islamic fundamentalism and the Arab Spring. See Matthies-Boon, forthcoming 2012.

8 Apart from the Eastern and Central European states which were of course part of the Soviet empire for several decades: but Habermas has an ambiguous relation to the Central and Eastern European legacy and does not count these states as genuinely European. "Europe" for Habermas is definitely on the Western side of the Wall.

9 It is in fact also on this point that Habermas launched a public campaign against the neoconservative outlook in the 1980s (Habermas, 1989). Apart from their dubious relation to German history, one of his main criticisms was the neoconservatives' return to heavily freighted notions such as tradition, while upholding a blind belief in the free market. In Habermas's eyes, while they sought to compensate for the one-sided instrumental rationality of the market in their stated reliance on, for example, tradition, instrumental rationality can be compensated for only by communicative processes. He thus insisted that we should not revert to pre-modern notions of tradition or to irrational concepts of culture, but rather move forward and look to establish a deliberative social order (see Habermas, 1985, 1987a).

10 States that have in place the necessary governmental support for the growth of free enterprise.

11 They have held annual meetings since 1998 and have provided a forum for this increasingly close cooperation behind the scenes (Cammack, 2006, p. 11).

12 See Boon (2009) for a more detailed analysis of this problem in Habermas's work. Also see Honneth and Joas (1988). 
13 Democratic peace theory, while popular not only among politicians but also among international relations scholars, is problematic in that it looks primarily at the conflict between states rather than between states and non-state actors, which is one of the most common forms of conflict in our time. It also fails to account for the amount of violence that occurs once a state makes a transition towards democracy and thus only takes the end result, a fully-fledged established democracy, as its unit of analysis. When imposed by force, of course, it entangles itself in contradiction.

14 Within American political science the debate on the Wilsonian legacy and the Bush administration is too extensive to do justice to here: see, among others, Ambrosius, 2006; Fleming, 2003a, 2003b; Hoff, 2007; Kennedy, 2005; Levine, 2006.

15 This fear is also largely based on the Algerian case in the 1990s where a military coup supported by Western forces took aim to prevent the election into government of the Islamic Salvation Front. Since the failures of the invasion in Iraq and the entanglements the American administration got itself into, this fear has returned and a more pragmatic approach based on realist rather than idealist concerns returned to the White House (see Roy, 2008).

\section{References}

Ambrosius, L. E. (2006). Woodrow Wilson and George W. Bush: Historical comparisons of ends and means in their foreign policies. Diplomatic History 30, 509-543.

Annan, K. (1997). Secretary-General in address to World Economic Forum, stressing partnership between United Nations, private sector. [Press Release]. Retrieved from http://www.un.org/News/Press/docs/1997/19970131.sgsm6153.html

Berger, M. T. (2001). The rise and demise of national development and the origins of post-cold war capitalism. Millennium: Journal of International Studies, 30, 211-234.

Boon, V. (2007). Habermas's writings on Europe: Not Habermasian enough? Ethical Perspectives, 14, 287-310

Boon, V. (2009). On a Europe without controversial learning curves: Using Habermas against Habermas (Unpublished doctoral dissertation). University of Liverpool, Liverpool.

Boon, V., (2010). Jürgen Habermas and Islamic fundamentalism: On the limits of discourse ethics. Journal of Global Ethics, 6, 153-166

Bush, G. W. (2003). George Bush's speech to the American Enterprise Institute. Retrieved from http://www.guardian.co.uk/world/2003/feb/27/usa.iraq2

Cammack, P. (2006). UN Imperialism: Unleashing entrepreneurship in the developing world. Papers in the Politics of Global Competitiveness, No. 2, Institute for Global Studies. Manchester Metropolitan University, Manchester.

Dueck, C. (2003). Hegemony on the cheap: Liberal internationalism from Wilson to Bush. World Policy Journal, 20, 1-11.

Encarnación, O. G. (2005). The Follies of Democratic Imperialism. World Policy Journal, 22(1), 47-60.

Fleming, T. (2003a, May 19). President Bush's Woodrow Wilson problem. Retrieved from http://hnn.us/articles/1451.html

Fleming, T. (2003b, September 8). What we're grappling with in Iraq is Woodrow Wilson's legacy. Retrieved from http://hnn.us/articles/1668.html

Gerson, M. (1996). The neoconservative vision: From the Cold War to culture wars. New York, NY: Madison Books.

Habermas, J. (1979a). Communication and the evolution of society. Boston, MA: Beacon Press.

Habermas, J. (1979b). History and evolution. Telos, 39, 5-44.

Habermas, J. (1984). The theory of communicative action volume 1. Reason and the rationalization of society. Cambridge: Polity Press.

Habermas, J. (1985). Modernity - an incomplete project. In H. Foster (Ed), Postmodern Culture (pp. 315). London: Pluto Press.

Habermas, J. (1987a). The philosophical discourse of modernity. Cambridge: Polity Press.

Habermas, J. (1987b). The theory of communicative action, Volume 2. Lifeworld and system: A critique of functionalist reason. Cambridge: Polity Press. 


\section{Vivienne Matthies-Boon}

Habermas, J. (1989). The new conservatism: Cultural criticism and the historians debate. Cambridge, MA: MIT University Press.

Habermas, J. (1996). Between facts and norms: Contributions to a discourse theory of law and democracy. Cambridge: Polity Press.

Habermas, J. (1997a). Kant's perpetual peace, with the benefit of 200 year's hindsight. In J. Bohman \& M. Lutz-Bachmann (Eds.), Perpetual peace: Essays on Kant's cosmopolitan ideal (pp. 113-134). Cambridge, MA: MIT University Press.

Habermas, J. (2001). The postnational constellation. Cambridge: Polity Press.

Habermas, J. (2003). Fundamentalism and terror. In G. Borradorri (Ed.) Philosophy in a time of terror: Dialogues with Jürgen Habermas and Jacques Derrida (pp. 25-45). Chicago, IL: University of Chicago Press.

Habermas, J. (2004). America and the World: A conversation with Jürgen Habermas with Eduardo Mendieta. Logos Journal, 3(3). Retrieved from http://www.logosjournal.com/habermas_america.htm

Habermas, J. (2005). February 15, or, what binds Europeans together: Plea for a common foreign policy, beginning in core Europe. In D. Levy, M. Pensky, \& J. Torpey (Eds.) Old Europe, new Europe, core Europe (pp. 3-14). London: Verso.

Habermas, J. (2006a). The Divided West. Cambridge: Polity Press.

Habermas, J. (2006b). Time of transitions. Cambridge: Polity Press.

Habermas, J. (2009). Europe: The faltering project. Cambridge: Polity Press.

Honneth, A., \& Joas, H. (1988). Social action and human nature. Cambridge: Cambridge University Press.

Hassan, O. (2009). George W. Bush, September the $11^{\text {th }}$ and the rise of the freedom agenda in USMiddle East relations: A constructivist institutionalist approach. (Doctoral dissertation). Retrieved from http://etheses.bham.ac.uk/399/

Hoff, J. (2007). A faustian foreign policy from Woodrow Wilson to George W. Bush: Dreams of perfectibility. Cambridge: Cambridge University Press.

Kennedy, D. M. (2005). What "W" owes to "WW." Atlantic, 295. Retrieved from $\mathrm{http} / / /$ theatlantic.com/doc/200503/kennedy

Khan, A. (2011). A portfolio theory of foreign affairs: The US relations with the Muslim World. Transnational Law and Contemporary Problems, 91, 377-410.

Levine, P. (2006). George W. Bush and Woodrow Wilson. Retrieved from http://www.peterlevine.ws/mt/archives/000811.html

Matthies-Boon, V. (in print). Jürgen Habermas and the democratisation of Islamic fundamentalism: The case of the Egyptian Muslim Brotherhood. In T. Bailey (Ed.) Habermas from Global Perspectives. London: Routledge.

Müller, J.-W. (2000). Another country: German intellectuals, unification and national identity. New Haven, CT: Yale University Press.

Rosenfeld, M. (2007). Habermas's call for cosmopolitan constitutional patriotism in an age of global terror: A pluralist appraisal. Constellations, 14, 159-181.

Roy, O. (1998). The failure of political Islam. New Haven, CT: Harvard University Press.

Roy, O. (2008). The politics of chaos in the Middle East. New York, NY: Columbia University Press.

UN Senior Management Group. (2011). Mark Malloch Brown. Retrieved from http://www.un.org/News/ossg/sg/stories/dsgbio.asp

Yoo, J. C., \& Delahunty, R. J. (2010). Kant, Habermas and democratic peace. Chicago Journal of International Law, 11, pp.1-37. Retrieved from http://works.bepress.com/johnyoo/51 